\title{
Bioeconomic Performance of Pullets and Layer Hens Fed Soybean Grains-Based Diets in Hot and Humid Climate
}

\author{
M. F. Houndonougbo, C. A. A. M. Chrysostome, F. Daga Dadjo, and S. L. Adjaho \\ Faculty of Agronomic Sciences, University of Abomey Calavi, 01 BP 526 Cotonou, Benin \\ Correspondence should be addressed to M. F. Houndonougbo, fredericmh@gmail.com
}

Received 24 February 2012; Accepted 30 March 2012

Academic Editors: E. Bártová and A. Berman

Copyright (๑) 2012 M. F. Houndonougbo et al. This is an open access article distributed under the Creative Commons Attribution License, which permits unrestricted use, distribution, and reproduction in any medium, provided the original work is properly cited.

\begin{abstract}
The aim of this paper was to evaluate the effects of toasted soybean grains on bioeconomic performance of pullets and layer hens in hot and humid environment. A total of 972 three-week-old Harco chicks were divided into 12 groups. At starter, pullet and laying phases, birds were fed four diets containing $0 \%(\mathrm{R} 0), 5 \%$ (R5), 10\% (R10), and 15\% (R15) of soybean grains. Results showed similar feed intake, body weight gain, laying rate, feed conversion ratio, and mortality rate between dietary treatments at each phase. The egg weight increased significantly in diet R15 $(P<0.05)$. The use of soybean grains reduced the feed prices. Feeding cost decreased significantly $(P<0.05)$ during growth and laying phases in soybean grains added diets. Feeds efficiency increased significantly $(P<0.05)$ with the increase of dietary soybean grains rate. Properly toasted soybean grains can be therefore included up to $15 \%$ in heavy line layer hens' diet in tropical conditions.
\end{abstract}

\section{Introduction}

Soybean meal is an ingredient of choice to supply energy and proteins to layers and broilers. Because of that, costs and availability of soybean meal are strongly correlated with the price of agricultural commodities on the world market $[1,2]$.

However, soybean grains are more used in broilers diets than layers diets. Soybean grains are known for their high content of fat. The trypsin inhibitors of soybean grain are well characterized and are an important determinant of nutritive value $[3,4]$. Properly processed whole soybean grains may be used effectively for poultry [5] and pigs [2]. Toasting is suggested within other heat processing procedures to reduce trypsin inhibitors in soybean grains or meals $[6,7]$. In Benin, only Jupiter variety of soybean is produced; and the toasting method is adopted for processing grains and meal [8].

On other side, laying performance of hens is lower when they are too fat. Thus, soybean grains even toasted are used at lower rate in pullets and layers diets than broilers diets. Farmers reject the utilization of toasted soybean grains in layers diet in Benin; but [8] included efficiently up to $22 \%$ of toasted soybean grains in broiler diet.
In tropical climate, important increase of dietary energy may be result a decrease of feed intake by poultry. Toasted soybean grains have a high content of energy and protein, it is important to evaluate their optimal rate in diets of pullets and layer hens in hot and humid climate, mainly for birds from heavy lines often used in Africa.

\section{Materials and Methods}

2.1. Animals and Housing. The study was conducted in a poultry house $(20 \mathrm{~m} \times 15 \mathrm{~m})$. The house was divided into twelve (12) partitions of $25 \mathrm{~m}^{2}$ each. Each partition had three feeders ( $1.5 \mathrm{~m}$ of length) and two automatic drinkers.

A total of 1000 Harco (Rhode Island Red $\times$ Plymouth Rock) day-old chicks were imported from Nigeria. They were vaccinated against Newcastle disease, Gumboro, infectious bronchitis, and avian pox. Chicks were also treated regularly against helminthes and coccidiosis.

At three-week-old (starting of the experiment), the average weight of chicks was $206.5 \pm 2.69 \mathrm{~g}$. Chicks were divided into 12 groups of 81 chicks each. Thus, at pullet and laying phases, there were 3.2 chicks $/ \mathrm{m}^{2}$. Each diet was fed in 3 replicates. 
TABLE 1: Ingredients and chemical composition of diets as formulated at starter phase (4- to 8-week-old).

\begin{tabular}{lcccc}
\hline Ingredients (\%) & $\mathrm{R} 0$ & $\mathrm{R} 5$ & $\mathrm{R} 10$ & $\mathrm{R} 15$ \\
\hline Soybean grains $^{1}$ & - & 5 & 10 & 15 \\
Maize grain & 60.35 & 55.35 & 54.35 & 53.35 \\
Wheat bran & 13 & 19 & 19 & 19 \\
Soybean meal & 15 & - & - & - \\
Cotton meal $^{2}$ & 5 & 10 & 8 & 6 \\
Oyster shell & 1 & 1 & 1 & 1 \\
Lysine & 0.1 & 0.1 & 0.1 & 0.1 \\
Methionine & 0.2 & 0.2 & 0.2 & 0.2 \\
Phosphate bicalcium & 0.1 & 0.1 & 0.1 & 0.1 \\
Premix & 0.25 & 0.25 & 0.25 & 0.25 \\
Concentrated broilers & 5 & 9 & 7 & 5 \\
\hline Chemical composition & & & & \\
$\quad$ Dry matter (\%) & 86.5 & 86.9 & 86.8 & 86.7 \\
Crude fiber (\%) & 4.3 & 4.6 & 4.7 & 4.7 \\
$\quad$ Metabolisable energy (kcal/kg) & 2761.2 & 2717.8 & 2793 & 2868 \\
Crude protein (\%) & 17.8 & 17.6 & 17.6 & 17.7 \\
$\quad$ Lysine (\%) & 0.92 & 0.87 & 0.89 & 0.91 \\
Methionine (\%) & 0.56 & 0.61 & 0.58 & 0.55 \\
Methionine + cystine (\%) & 0.85 & 0.88 & 0.86 & 0.85 \\
Calcium (\%) & 0.84 & 1.10 & 0.97 & 0.83 \\
Total phosphorus (\%) & 0.75 & 0.96 & 0.88 & 0.80 \\
\hline
\end{tabular}

${ }^{1}$ Toasted soybean grains made in Benin.

${ }^{2}$ Ferrous sulphate $\left(\mathrm{FeSO}_{4}\right)$ was added at the rate of $3 \mathrm{~g}$ per $\mathrm{kg}$ of cotton meal. ${ }^{3}$ Premix contained per kg: vitamins: A 4000000 UI, D3 800000 UI, E $2000 \mathrm{mg}, \mathrm{K} 800 \mathrm{mg}, \mathrm{B} 1600 \mathrm{mg}$, B2 $2000 \mathrm{mg}$, niacin $3600 \mathrm{mg}$, B6 $1200 \mathrm{mg}$, B12 $4 \mathrm{mg}$, and choline chloride $80000 \mathrm{mg}$; minerals: $\mathrm{Cu} 8000 \mathrm{mg}$, Mn $64000 \mathrm{mg}$, Zn $40000 \mathrm{mg}$, Fe $32000 \mathrm{mg}$, and Se $160 \mathrm{mg}$.

2.2. Experimental Diets and Feeding. Diets were formulated by phases. At starter ( 4 to 8 weeks-old), pullet (9 to 18) and laying (19 to 26) phases, respectively, four diets were formulated (Tables 1, 2, and 3). In diets, soybean grains were included at $0 \%$ (R0, control), 5\% (R5), 10\% (R10), and 15\% (R15). Soybean grains were toasted before the processing of diets to reduce trypsin inhibitors effect.

At each phase, the same quantity of feed was provided to each replicate and the birds consumed all the available feed. Birds were watered ad libitum. The prices per $\mathrm{kg}$ of formulated feed are presented in results. They are used to compare the efficiency of diets.

2.3. Statistical Analysis. The general linear model (GLM) was used to analyze data in SAS version 9.1.2 [10]. Mean values are presented in tables with the pooled standard error. A significant effect of diets is stated when $P$ value $(P)$ is less than 0.05 . The effects of replication and of the interaction between diets and replications were not significant $(P>0.05)$. Hence, the statistical model was

$$
Y_{i}=\mu+G_{i}+\varepsilon_{i}
$$

where $Y_{i}$ is the observation for dependent variables; $\mu$ is the general mean; $G_{i}$ is the fixed effect of soybean grains; $\varepsilon_{i}$ is the residual error.
TABLE 2: Ingredients and chemical composition of diets as formulated at pullet phase (9- to 18-week-old).

\begin{tabular}{|c|c|c|c|c|}
\hline Ingredients (\%) & R0 & $\mathrm{R} 5$ & $\mathrm{R} 10$ & $\mathrm{R} 15$ \\
\hline Soybean grains ${ }^{1}$ & - & 5 & 10 & 15 \\
\hline Maize grain & 56.15 & 60.15 & 52.15 & 51 \\
\hline Wheat bran & 7.6 & 6.6 & 9.6 & 11.6 \\
\hline Soybean meal & 14 & - & - & - \\
\hline Cotton meal ${ }^{2}$ & 7 & 10 & 10 & 7 \\
\hline Oyster shell & 1.7 & 1.7 & 1.7 & 1.7 \\
\hline Lysine & 0.1 & 0.1 & 0.1 & 0.1 \\
\hline Methionine & 0.2 & 0.2 & 0.2 & 0.2 \\
\hline Phosphate bicalcium & 1 & 1 & 1 & 1 \\
\hline Premix ${ }^{3}$ & 0.25 & 0.25 & 0.25 & 0.25 \\
\hline Concentrate broilers & 5 & 5 & 5 & 5 \\
\hline Maize bran & 7 & 10 & 10 & 7.15 \\
\hline \multicolumn{5}{|l|}{ Chemical composition } \\
\hline Dry matter (\%) & 87.2 & 87.2 & 87.3 & 87.2 \\
\hline Crude fiber (\%) & 4.63 & 4.45 & 4.93 & 5.13 \\
\hline Metabolisable energy ( $\mathrm{kcal} / \mathrm{kg})$ & 2819 & 2816 & 2817 & 2847 \\
\hline Crude protein (\%) & 15.92 & 15.39 & 15.88 & 15.75 \\
\hline Lysine $(\%)$ & 0.78 & 0.72 & 0.75 & 0.76 \\
\hline Methionine (\%) & 0.37 & 0.43 & 0.39 & 0.36 \\
\hline Methionine + cystine (\%) & 0.66 & 0.69 & 0.67 & 0.65 \\
\hline Calcium (\%) & 0.91 & 1.23 & 1.04 & 0.91 \\
\hline Total phosphorus (\%) & 0.64 & 0.82 & 0.74 & 0.67 \\
\hline
\end{tabular}

${ }^{1}$ Toasted soybean grains made in Benin.

${ }^{2}$ Ferrous sulphate $\left(\mathrm{FeSO}_{4}\right)$ were added at the rate of $3 \mathrm{~g}$ per $\mathrm{kg}$ of cotton meal.

${ }^{3}$ Premix contained per kg: vitamins: A 4000000 UI, D3 800000 UI, E $2000 \mathrm{mg}, \mathrm{K} 800 \mathrm{mg}$, B1 $600 \mathrm{mg}, \mathrm{B} 22000 \mathrm{mg}$, niacin $3600 \mathrm{mg}, \mathrm{B} 61200 \mathrm{mg}$, B12 $4 \mathrm{mg}$, and choline chloride $80000 \mathrm{mg}$; minerals: Cu $8000 \mathrm{mg}$, Mn $64000 \mathrm{mg}$, Zn $40000 \mathrm{mg}$, Fe $32000 \mathrm{mg}$, and Se $160 \mathrm{mg}$.

\section{Results}

The results are presented in two phases: the growth phase (starting and pullet phases) and the laying phase. They relate to feeding, growth, laying, and economic performance.

3.1. Performance of Pullets. Performances during the five weeks of starting phase are shown in Table 4 and Figure 1. The daily feed intake was maintained equal in all diets. No significant difference $(P>0.05)$ was recorded on, daily weight gain, mortality and feed conversion ratio in spite of difference in feed composition between diets. The inclusion of toasted soybean grains at different rates in the diet did not affect significantly the growth and survivability of chicks.

These results suggest a similar efficacy of diets at starter phase.

Also, during the pullet phase the growth performance was not significantly affected by the diet (Table 5 and Figure 1). However, the feed conversion ratio and the mortality rate increased at pullet compared to the starter phase.

At starter and pullet phases, the prices of the formulated feeds decreased when the soybean grains rate increased in the diet (Table 6). Thus, at pullet phase, the feeding cost per 


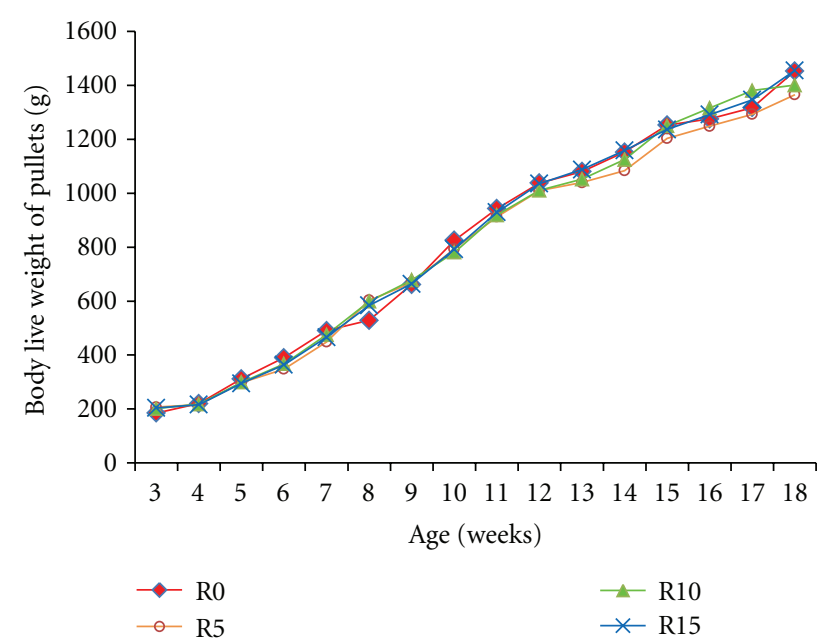

FIGURE 1: Growth curves of Harco pullets fed different rate of toasted soybean grains based diets. R0, R5, R10, and R15 are diets containing, respectively, $0,5,10$, and $15 \%$ of toasted soybean grains.

TABLE 3: Ingredients and chemical composition of diets as formulated at laying phase (19- to 26-week-old).

\begin{tabular}{lcccc}
\hline Ingredients (\%) & $\mathrm{R} 0$ & $\mathrm{R} 5$ & $\mathrm{R} 10$ & $\mathrm{R} 15$ \\
\hline Soybean grains $^{1}$ & - & 5 & 10 & 15 \\
Maize grain & 57.75 & 57.25 & 54.25 & 59.75 \\
Wheat bran & - & - & 2.5 & - \\
Soybean meal & 19 & 14.5 & 9.5 & - \\
Cotton meal $^{2}$ & 7 & 7 & 7.5 & 9 \\
Oyster shell $_{\text {Lysine }}$ & 10 & 10 & 10 & 10 \\
Methionine & 0.05 & 0.05 & 0.05 & 0.05 \\
Phosphate bicalcium & 0.15 & 0.15 & 0.15 & 0.15 \\
Premix & 0.8 & 0.8 & 0.8 & 0.8 \\
Concentrate layers & 0.25 & 0.25 & 0.25 & 0.25 \\
\hline Chemical composition & 5 & 5 & 5 & 5 \\
$\quad$ Dry matter (\%) & & & & \\
$\quad$ Crude fiber (\%) & 88.7 & 88.5 & 88.5 & 88.4 \\
$\quad$ Metabolisable energy (kcal/kg) & 2703 & 2702 & 2708 & 2814 \\
Crude protein (\%) & 18.2 & 18.2 & 18.2 & 18.55 \\
$\quad$ Lysine (\%) & 0.93 & 0.93 & 0.9 & 0.93 \\
Methionine (\%) & 0.51 & 0.51 & 0.50 & 0.59 \\
Methionine + cystine (\%) & 0.80 & 0.80 & 0.80 & 0.87 \\
Calcium (\%) & 4.38 & 4.38 & 4.4 & 4.60 \\
Total phosphorus (\%) & 0.75 & 0.74 & 0.8 & 0.83 \\
\hline
\end{tabular}

${ }^{1}$ Toasted soybean grains made in Benin.

${ }^{2}$ Ferrous sulphate $\left(\mathrm{FeSO}_{4}\right)$ were added at the rate of $3 \mathrm{~g}$ per $\mathrm{kg}$ of cotton meal.

${ }^{3}$ Premix contained per kg: vitamins: A 4000000 UI, D3 800000 UI, E $2000 \mathrm{mg}, \mathrm{K} 800 \mathrm{mg}, \mathrm{B} 1600 \mathrm{mg}$, B2 $2000 \mathrm{mg}$, niacin $3600 \mathrm{mg}$, B6 $1200 \mathrm{mg}$, B12 $4 \mathrm{mg}$, and choline chloride $80000 \mathrm{mg}$; minerals: $\mathrm{Cu} 8000 \mathrm{mg}, \mathrm{Mn}$ $64000 \mathrm{mg}$, Zn $40000 \mathrm{mg}$, Fe $32000 \mathrm{mg}$, and Se $160 \mathrm{mg}$.

$\mathrm{kg}$ of live body weight gain decreased in soybean-based diets compared to the control diet (Table 7). However, at starter phase, due to the light decrease of live body weight gain in the soybean grains-based diets, the feeding cost increased

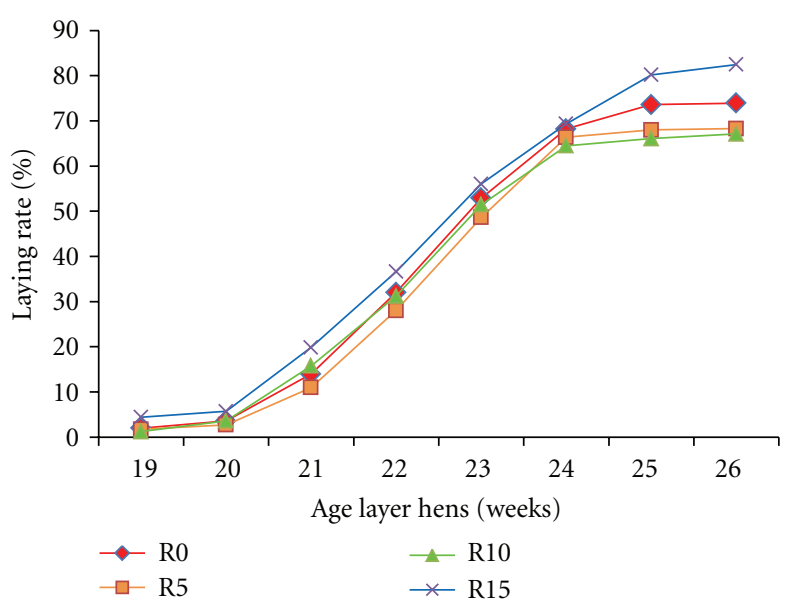

Figure 2: Laying rate of Harco hens fed different rate of toasted soybean grains. R0, R5, R10, and R15 are diets containing, respectively, $0,5,10$, and $15 \%$ of toasted soybean grains.

(Table 6). The soybean grains based diets are therefore more efficient at pullet phase than at starter phase.

The feed efficiency evaluated at the end of pullet phase, demonstrated that for each unit of money invested in feed, the revenue from the selling of the live weight gain varied between 2.15 and 2.48 times (Table 7). The efficiency of the diet increased significantly $(P<0.05)$ with an increase of the toasted soybean grains rate.

3.2. Performance of Laying Hens. The laying phase was recorded until the peak of lay between 25 and 26 week-old (Figure 2). While feed intake was equal between treatments, the results demonstrated an improvement of laying rate in layers fed R15 diet compared to the control diet. In the second month, the average laying rate in R15 was $67.8 \%$ versus $64.7 \%$ in control diet, without any significant difference between treatments. At the peak (26-week-old), laying rates were $73.9 \%, 68.3 \%, 67.1 \%$, and $82.5 \%$ in R0, R5, R10, and R15 diets, respectively.

Furthermore, the egg weight of layers fed R15 diet increased significantly $(P<0.05)$ in the second month of laying (Table 8). Thus, during the two first months of laying the feed conversion of layers fed R15 was the lowest, and there was no significant effect of diet on mortality rate of hens $(P>0.05)$.

The price of diet was lower in soybean grains diets. Thus, the feeding cost per egg decreased significantly during the first month of laying, but not later (Table 9). Respectively, in first and second months, the feeding cost in R15 diet represented about $32 \%$ and $86 \%$ of that in control diet, indicating a better efficiency of R15 diet compared to the control diet and the two other soybean grains-based diets.

\section{Discussion}

4.1. Growth Performance of Pullets. The similarity on growth performance of pullets up to 18 -week-old demonstrates the efficiency of toasted soybean grains based diets in general and 
TABLE 4: Feeding and growth performance of pullet chicks from 4 to 8 weeks of age.

\begin{tabular}{|c|c|c|c|c|c|c|}
\hline & $\mathrm{R} 0^{1}$ & R5 & $\mathrm{R} 10$ & R15 & SE & $P^{3}$ \\
\hline Daily feed intake (g/day) & 41 & 41 & 41 & 41 & - & - \\
\hline Final live body weight (g) & 529.4 & 603.1 & 599.3 & 564.5 & 36.1 & 0.75 \\
\hline Daily weight gain (g/day) & 12.7 & 11.34 & 11.38 & 10.84 & 1.56 & 0.85 \\
\hline Mortality rate (\%) & 0.00 & 0.25 & 0.25 & 0.08 & 0.10 & 0.23 \\
\hline Feed conversion ratio ${ }^{4}$ & 1.74 & 1.86 & 1.81 & 1.84 & 0.13 & 0.92 \\
\hline
\end{tabular}

${ }^{1} \mathrm{R} 0, \mathrm{R} 5, \mathrm{R} 10$, and R15 are diets containing respectively $0,5,10$, and $15 \%$ of toasted soybean grains.

${ }^{2}$ Standard error; ${ }^{3} P$ value; ${ }^{4} \mathrm{~kg}$ feed $/ \mathrm{kg}$ live body weight gain.

TABLE 5: Feeding and growth performance of pullets from 9 to 18 weeks of age.

\begin{tabular}{|c|c|c|c|c|c|c|}
\hline & $\mathrm{R}^{1}$ & R5 & $\mathrm{R} 10$ & R15 & SE & $P^{3}$ \\
\hline Daily feed intake (g/day) & 78.0 & 78.0 & 78.0 & 78.0 & - & - \\
\hline Final live body weight (g) & 1454 & 1366 & 1401 & 1456 & 29.9 & 0.73 \\
\hline Daily weight gain (g/day) & 13.9 & 13.4 & 13.9 & 14.6 & 1.36 & 0.74 \\
\hline Mortality rate (\%) & 0.16 & 0.38 & 0.35 & 0.69 & 0.14 & 0.08 \\
\hline Feed conversion ratio ${ }^{4}$ & 3.69 & 3.82 & 3.75 & 3.69 & 0.11 & 0.8 \\
\hline
\end{tabular}

${ }^{1} \mathrm{R} 0, \mathrm{R} 5, \mathrm{R} 10$, and R15 are diets containing respectively $0,5,10$, and $15 \%$ of toasted soybean grains.

${ }^{2}$ Standard error; ${ }^{3} \mathrm{P}$-value; ${ }^{4} \mathrm{~kg}$ feed $/ \mathrm{kg}$ live body weight gain.

TABLE 6: Economic performance during the starter phase (4 to 8 weeks of age).

\begin{tabular}{|c|c|c|c|c|c|c|}
\hline & $\mathrm{R} 0^{1}$ & R5 & $\mathrm{R} 10$ & $\mathrm{R} 15$ & SE & $P^{3}$ \\
\hline Price of formulated feed (FCFA $* / \mathrm{kg})$ & 234 & 227 & 223 & 219 & - & - \\
\hline Feeding cost (FCFA/kg body weight gain) & $877.1^{\mathrm{a}}$ & $1383.4^{\mathrm{b}}$ & $1174.8^{\mathrm{c}}$ & $1459.8^{\mathrm{b}}$ & 866 & 0.02 \\
\hline
\end{tabular}

$\overline{\mathrm{a}, \mathrm{b}, \mathrm{c}}$ Means with unlike superscripts in the same row differ significantly $(P<0.05)$.

${ }^{1} \mathrm{R} 0, \mathrm{R} 5, \mathrm{R} 10$, and $\mathrm{R} 15$ are diets containing respectively $0,5,10$, and $15 \%$ of toasted soybean grains.

${ }^{2}$ Standard error; ${ }^{3} P$-value; $* 1 €=655.9$ FCFA.

TABLE 7: Economic performances during pullet phase ( 9 to 18 weeks of age).

\begin{tabular}{|c|c|c|c|c|c|c|}
\hline & $\mathrm{R}^{1}{ }^{1}$ & R5 & $\mathrm{R} 10$ & $\mathrm{R} 15$ & SE & $P^{3}$ \\
\hline Price of formulated feed (FCFA*/kg) & 202 & 206 & 197 & 192 & - & - \\
\hline Feeding cost (FCFA/kg weight gain) & $1908.4^{\mathrm{a}}$ & $1677.6^{\mathrm{b}}$ & $1649.5^{\mathrm{b}}$ & $1323.7^{c}$ & 1079 & 0.04 \\
\hline Economic feed efficiency ${ }^{4}$ & $2.37^{\mathrm{a}}$ & $2.15^{\mathrm{b}}$ & $2.30^{\mathrm{a}}$ & $2.48^{\mathrm{c}}$ & 0.08 & 0.03 \\
\hline
\end{tabular}

${ }_{\mathrm{a}, \mathrm{b}, \mathrm{c}}$ Means with unlike superscripts in the same row differ significantly $(P<0.05)$.

${ }^{1} \mathrm{R} 0$, R5, R10, and R15 are diets containing respectively $0,5,10$, and $15 \%$ of toasted soybean grains.

${ }^{2}$ Standard error; ${ }^{3} P$-value; ${ }^{*} 1 €=655.9$ FCFA

${ }^{4}$ (FCFA Body weight gain/FCFA feed): revenue from weight gain/feeding cost, according to [9].

TABLE 8: Feeding and laying performances of layer hens fed different rate of toasted soybean grains between 19- and 26-week-old.

\begin{tabular}{lccccccc}
\hline & Laying months & R0 & R5 & R10 & R15 & SE & $P^{3}$ \\
\hline \multirow{2}{*}{ Daily feed intake (g/day) } & 1 & 113.8 & 113.8 & 113.8 & 113.8 & - & - \\
& 2 & 120 & 120 & 120 & 120 & - & - \\
Egg weight (g) & 1 & 44.9 & 46.1 & 45.1 & 44.1 & 1.28 & 0.78 \\
& 2 & $52.0^{\mathrm{a}}$ & $51.4^{\mathrm{a}}$ & $52.4^{\mathrm{a}}$ & $55.1^{\mathrm{b}}$ & 0.72 & 0.004 \\
Mortality rate (\%) & 1 & 0.31 & 0.22 & 0.55 & 0.11 & 0.19 & 0.44 \\
& 2 & 1.09 & 0.89 & 0.56 & 1.15 & 0.31 & 0.56 \\
Feed conversion ratio (kg feed/kg egg) & 1 & $20.3^{\mathrm{a}}$ & $26.7^{\mathrm{b}}$ & $20.9^{\mathrm{a}}$ & $16.9^{\mathrm{a}}$ & 1.84 & 0.005 \\
& 2 & $7.16^{\mathrm{a}}$ & $7.97^{\mathrm{b}}$ & $7.88^{\mathrm{b}}$ & $6.36^{\mathrm{a}}$ & 0.37 & 0.014 \\
\hline
\end{tabular}

$\overline{\mathrm{a}, \mathrm{b}}$ Means with unlike superscripts in the same row differ significantly $(P<0.05)$.

${ }^{1} \mathrm{R} 0, \mathrm{R} 5, \mathrm{R} 10$, and R15 are diets containing, respectively $0,5,10$, and $15 \%$ of toasted soybean grains.

${ }^{2}$ Standard error; ${ }^{3} P$-value. 
TABLE 9: Economic performances of layer hens fed different rate of toasted soybean grains.

\begin{tabular}{lccccccc}
\hline & Laying month & R0 & R5 & R10 & R15 & SE & $P^{3}$ \\
\hline Feed price (FCFA*/kg) & - & 270 & 260 & 255 & 260 & - & - \\
Feeding cost (FCFA/Egg) & 1 & $2142.7^{\mathrm{a}}$ & $1930.9^{\mathrm{a}}$ & $1700.5^{\mathrm{a}}$ & $1652.8^{\mathrm{b}}$ & 681.0 & 0.04 \\
& 2 & 54.8 & 57.2 & 55.2 & 47.3 & 4.21 & 0.37 \\
\hline
\end{tabular}

${ }^{\mathrm{a}, \mathrm{b}}$ Means with unlike superscripts in the same row differ significantly $(P<0.05)$.

${ }^{1} \mathrm{R} 0, \mathrm{R} 5, \mathrm{R} 10$ and $\mathrm{R} 15$ are diets containing respectively $0,5,10$, and $15 \%$ of toasted soybean grains.

${ }^{2}$ Standard error; ${ }^{3} P$-value;

$* 1 €=655.9$ FCFA.

R15 diet in particular. The live body weight gain of pullets was higher than reported [11], and they grew regularly. Thus, the final weights of pullets (1366 to $1456 \mathrm{~g}$ ) are in the range of 1341 to $1594 \mathrm{~g}$ recorded at 20-week-old in Shika-Brown pullets. The live weight of pullets at the starting of the laying period is one of more important criteria focused by farmers. In this study, at 18 -week-old the live weight of pullets was very similar in R0 and R15 diets (1454 g versus $1456 \mathrm{~g}$ ).

During pullet phase the feed conversion ratios were lower than the 5.73 to 6.62 found between 8 and 20 weeks in Hyline pullets [12]. Furthermore, the light increase of mortality rate in soybean based diets compared to control diet was not significant. These results confirmed the efficacy of all the diets. Up to $15 \%$ of toasted soybean grain can be therefore included into pullets' diets in hot and humid climate.

4.2. Laying Performance of Hens. Up to peak, the laying rate in R15 diet was the highest, with a significant difference from 24 to 26 weeks of age. Thus, efficiency of toasted soybean grains based diets was also effective during the first eight laying weeks. The average laying rate was higher than $63.8-68.4 \%$ [13], 64.0\% [14], and 61.4\% [12] recorded respectively with Harco and Hy-line layers up to 28 -weekold. At laying phase, the feed conversion ratio was also lower in R15 diet compared to the control diet. However, the feed conversion ratios were higher than $2.81-4.07 \mathrm{~g}$ feed $/ \mathrm{g}$ egg [12].

No significant diet effect was found on hens' mortality. In the second month, the egg weights were significantly higher in R15 diet, but lower than the $60 \mathrm{~g}$ reported by other [1517]. In first month, the egg weights were in the range of 41.0 $47.4 \mathrm{~g}$ [14].

Energy requirement of hens is lower in hot and humid climate than in temperate climate. Soybean grains being very energetic, during the latest laying weeks, hens could get fat. That might reduce their laying performance. An evaluation of the laying performance during the whole laying period is therefore relevant for heavy layers breeds fed with whole toasted soybean grains in hot and humid climate.

4.3. Economic Performance of Pullets and Hens. The incorporation of toasted soybean grains in diets reduces feed prices. At growth and laying phases, the lowest feeding cost was in R15 diet. Thus, feeding cost and feed efficiency improved significantly in soybean-based diets during the growth phase of pullets. The feeding of Harco pullets with toasted soybean grains diets can be therefore recommended in hot and humid regions. The significant decrease of feeding cost from first to second laying months was due to the increase of laying rate until the peak.

\section{Conclusion}

This study shows the efficiency of toasted soybean-based diets in Harco pullets and hens feeding in hot and humid climate. The toasting processing used in Benin to improved soybean grain efficacy in poultry diet is therefore suitable. However, the price of toasted soybean grains should be kept at a level where the energy and protein costs from these grains should be lower than those from other main energy and protein sources like soybean and fish meals.

\section{Acknowledgment}

The authors are grateful to the Enterprise Services and Producers Organization (ESOP-NGO/Enterprise Territory and Development) for the gift of toasted soybean grains.

\section{References}

[1] A. Vicenti, F. Toteda, L. D. Turi et al., "Use of sweet lupin (Lupinus albus L. var. Multitalia) in feeding for Podolian young bulls and influence on productive performances and meat quality traits," Meat Science, vol. 82, no. 2, pp. 247-251, 2009.

[2] D. Jezierny, R. Mosenthin, and E. Bauer, "The use of grain legumes as a protein source in pig nutrition: a review," Animal Feed Science and Technology, vol. 157, no. 3-4, pp. 111-128, 2010.

[3] J. P. F. D’Mello, “Antinutritional substances in legume seeds," in Tropical Legumes in Animal Nutrition, J. P. F. D'Mello and C. Devendra, Eds., pp. 135-172, CAB International, London, UK, 1995.

[4] K. L. Herkelman, G. L. Cromwell, and T. S. Stahly, "Effects of heating time and sodium metabisulfite on the nutritional value of full-fat soybeans for chicks," Journal of Animal Science, vol. 69, no. 11, pp. 4477-4486, 1991.

[5] P. W. Waldroup, "Whole soybeans for poultry feeds," World's Poultry Science Journal, vol. 38, pp. 28-35, 1982.

[6] M. Friedman, D. L. Brandon, A. H. Bates, and T. Hymowitz, "Comparison of a commercial soybean cultivar and an isoline lacking the kunitz trypsin inhibitor: composition, nutritional value, and effects of heating," Journal of Agricultural and Food Chemistry, vol. 39, no. 2, pp. 327-335, 1991.

[7] P. McDonald, R. A. Edwards, J. F. D. Greenhalgh, and C. A. Morgan, Animal Nutrition, Pearson Education, Harlow, UK, 6th edition, 2002. 
[8] F. M. Houndonougbo, A. Chwalibog, and C. A. A. M. Chrysostome, "Is the nutritional value of grains in broiler chickens' diets affected by environmental factors of soybean (Glycine max) growing and the variety of maize (Zea maize) in Benin?" Livestock Research for Rural Development, vol. 21, no. 2, article 22, 2009.

[9] F. M. Houndonougbo, A. Chwalibog, and C. A. A. M. Chrysostome, "Nutritional and economic values of by-products used in poultry diets in Benin: the case of soybean, cotton and palm kernel meals," Livestock Research for Rural Development, vol. 20, no. 11, article 174, 2008.

[10] SAS Institute Inc, Qualification Tools User's Guide Statistic, Analysis System Procedure, Version 9.1.2, SAS Institute Inc, Cary, NC, USA, 2004.

[11] F. O. Abeke, S. O. Ogundipe, A. A. Sekoni et al., "Growth and subsequent egg production performance of Shika-Brown pullets fed graded levels of cooked Lablab purpureus beans," Pakistan Journal of Biological Sciences, vol. 10, no. 7, pp. 10561061, 2007.

[12] M. A. Al-Harthi, "Utilization of treated mangrof leaves meal in pullet diets and its effect on subsequent hens performance," International Journal of Poultry Science, vol. 5, no. 7, pp. 598606, 2006.

[13] T. S. Olugbemi, S. K. Mutayoba, and F. P. Lekule, "Evaluation of Moringa oleifera leaf meal inclusion in cassava chip based diets fed to laying birds," Livestock Research for Rural Development, vol. 22, no. 6, article 118, 2010.

[14] A. A. Odunsi, "Effect of feeding reject cashew kernel meal on pre and early-laying performance of pullet," Archivos de Zootecnia, vol. 51, pp. 423-429, 2002.

[15] O. O. Tewe and M. Bokanga, "Cost effective cassava-plant based rations for poultry and pigs," in Proceedings of the 8th International Society for Tropical Root Crops-Africa Branch symposium, pp. 229-234, Ibadan, Nigeria, 2001.

[16] R. I. Salami and A. A. Odunsi, "Evaluation of processed cassava peel meals as substitutes for maize in the diets of layers," International Journal of Poultry Science, vol. 2, no. 2, pp. 112 116, 2003.

[17] B. O. Esonu, O. O. Azubuike, O. O. Emenalom, E. B. Etuk, H. Okoli, and C. S. Nneji, "Effect of enzyme supplementation on the performance of broiler finisher fed Microdesmis puberula leaf meal," International Journal of Poultry Science, vol. 3, no. 2, pp. 112-114, 2004. 

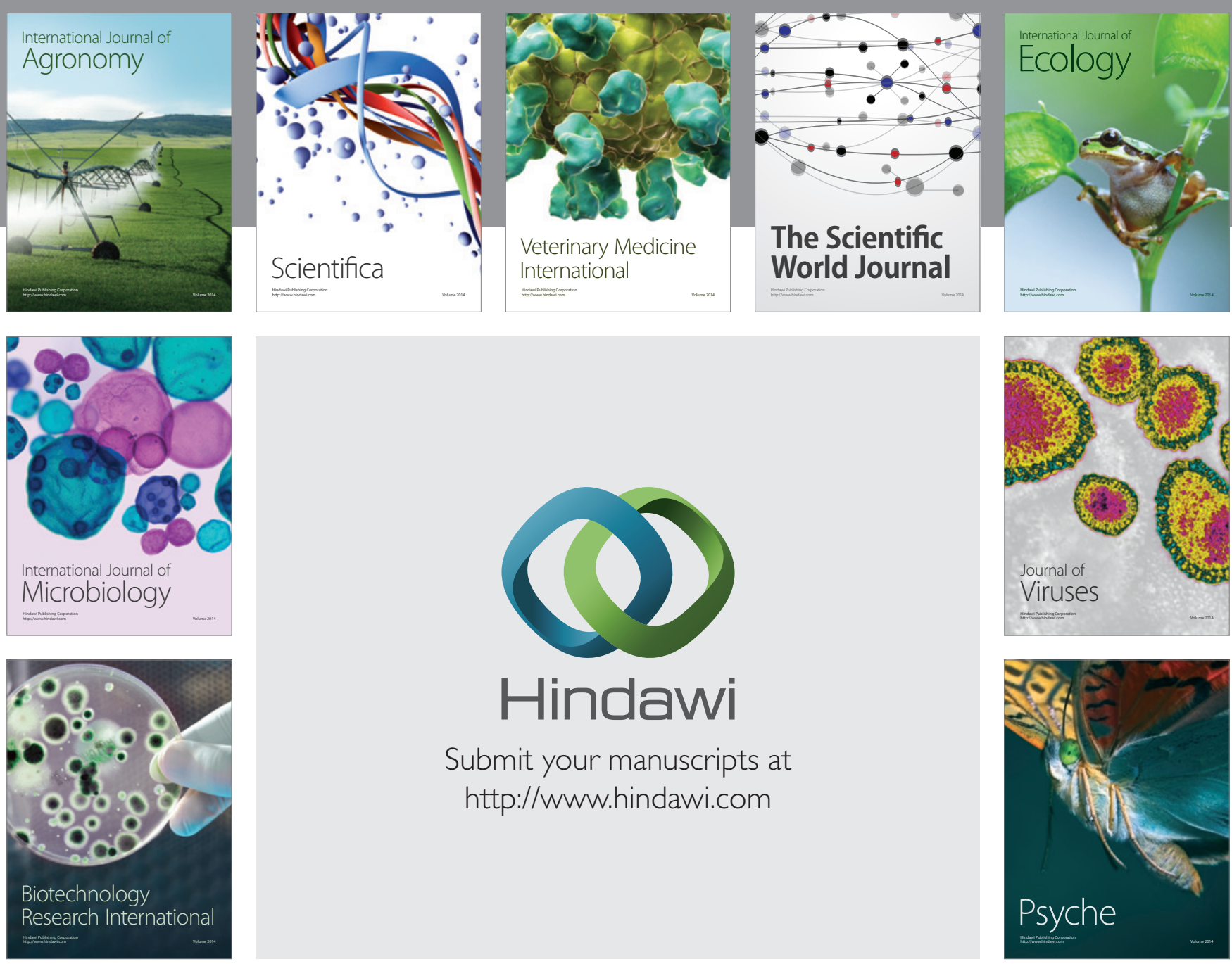

Submit your manuscripts at http://www.hindawi.com
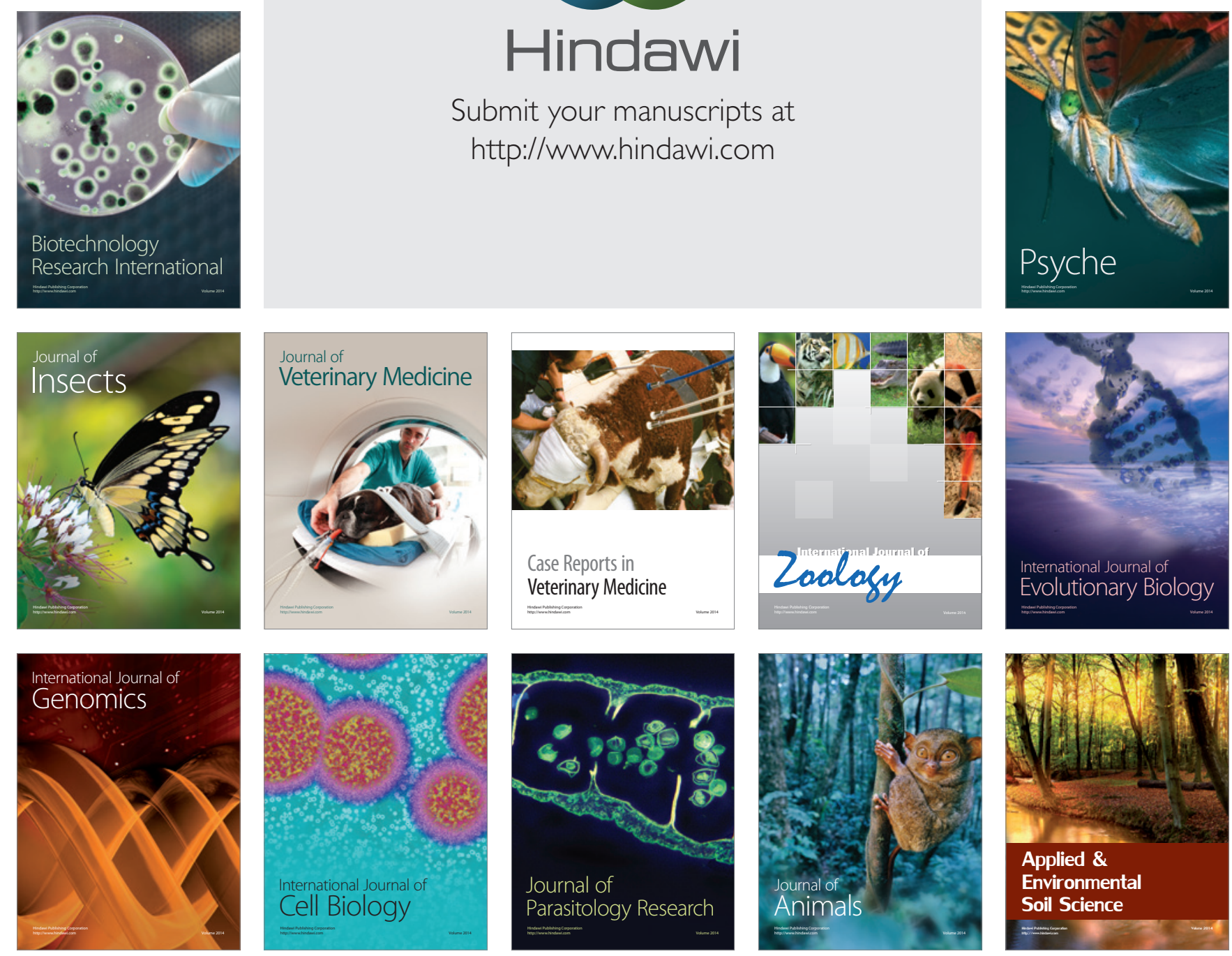